
\title{
$\begin{array}{ll}\text { Research Square } & \begin{array}{l}\text { Preprints are preliminary reports that have not undergone peer review. } \\ \text { They should not be considered conclusive, used to inform clinical practice, } \\ \text { or referenced by the media as validated information. }\end{array}\end{array}$
}

\section{Large-sized artificial photosynthetic cells with a solar-to-formate conversion efficiency of $7.2 \%$}

Naohiko Kato ( $\square$ n-kato@mosk.tytlabs.co.jp )

Toyota Central Research and Development Laboratories, Inc. https://orcid.org/0000-0001-9158-1549

Shintaro Mizuno

Toyota Central Research and Development Laboratories, Inc.

Masahito Shiozawa

Toyota Central Research and Development Laboratories, Inc.

Natsumi Nojiri

Toyota Central Research and Development Laboratories, Inc.

Yasuaki Kawai

Toyota Central R\&D Laboratories, Inc.

Kazuhiro Fukumoto

Toyota Central Research and Development Laboratories, Inc.

Takeshi Morikawa

Toyota Central R\&D Labs.,Inc.

Yasuhiko Takeda

Toyota Central Research and Development Laboratories, Inc.

Article

Keywords: artificial photosynthesis, solar-to-formate conversion, efficiency

Posted Date: July 15th, 2020

DOI: https://doi.org/10.21203/rs.3.rs-39169/v1

License: (c) (i) This work is licensed under a Creative Commons Attribution 4.0 International License. Read Full License 


\section{Abstract}

Artificial photosynthesis, including solar-driven electrochemical (EC) reduction of $\mathrm{CO} 2$ to fuel, using photovoltaic (PV) cells is a promising $\mathrm{CO} 2$ recycling method. However, the scale-up of EC reactors lowers the solar-to-chemical conversion efficiency hSTC) due to large electric resistance of the electrode catalysts and insufficient supply of reactants. We designed a large-sized cell to convert $\mathrm{CO} 2$ to formate. It consists of five stacked electrodes (electrically parallel-connected) and six series-connected single-crystalline Si PV cells (area 1000 cm2). Low-resistivity anodes loaded with IrOx and cathodes loaded with Ru complex polymer on carbon support operate without a membrane between them at a low voltage of $1.90 \mathrm{~V}$. They generate a reaction current of $6.30 \mathrm{~A}$, owing to the homogeneous flow of the CO2-dissolved electrolyte to achieve a sufficient $\mathrm{CO} 2$ supply and good match between the PV and EC performances. The cell yields a conversion efficiency of $7.2 \%$ and the highest production rate reported for large cells.

\section{Introduction}

The net $\mathrm{CO}_{2}$ emissions must be reduced to address recent natural disasters caused by global warming ${ }^{1}$. The solar energy supplied to Earth's surface is 9600 times larger than the current total global energy consumption ${ }^{2}$. The natural carbon cycle is mainly controlled by photosynthesis; green vegetation uses solar energy to convert $\mathrm{CO}_{2}$ and water to hydrocarbon and oxygen $\left(\mathrm{O}_{2}\right)$. Therefore, the artificial photosynthetic solardriven reduction of $\mathrm{CO}_{2}$ to fuels and chemicals is a promising way to promote the carbon cycle thereby achieving a sustainable carbon-neutral society ${ }^{3}$. Solar-driven $\mathrm{CO}_{2}$ reduction has been extensively studied regarding this purpose as well as regarding water splitting and solar energy storage applications ${ }^{4-6}$.

Various approaches have been made to obtain energy-efficient and cost-effective reactions. Currently, photovoltaic (PV)-driven electrochemical reactor (EC) systems (PV-EC) $)^{7-10}$ and photoelectrochemical (PEC) cells ${ }^{11-13}$ exhibit higher solar-to-chemical energy conversion efficiencies $\left(\eta_{\mathrm{STC}}\right)$ than photocatalytic (PC) systems. A solar-to-hydrogen conversion efficiency $\left(\eta_{\mathrm{STH}}\right)$ of $30 \%$ was achieved with a combination of an InGaP/GaAs/GalnNAsSb triple-junction PV cell and two series-connected polymer electrolyte membrane electrolysers ${ }^{14}$. The $\eta_{\mathrm{STC}}$ values of CO and formate generation are lower than $\eta_{\mathrm{STH}}$ at present. A CO generation $\eta_{\mathrm{STC}}$ of $13.4 \%$ was reported based on the use of a GalnP/GalnAs/Ge triple-junction PV cell and bipolar membrane (BPM), which was utilized as a separator between the anode and cathode to drive the uphill reaction ${ }^{15}$. A PEC system yielded a formate generation $\eta_{\mathrm{STC}}$ of $10 \%$ based on the use of a GaAs $/ \mathrm{lnGaP} / \mathrm{TiO}_{2} / \mathrm{Ni}$ photoanode and Pd/C nanoparticle-coated Ti mesh cathode with a BPM ${ }^{16}$. However, the use of III-V group compound semiconductors is not suitable in practice due to the very high costs of these materials. This arises from much energy consumption during material mining and purification and difficulties in the fabrication of large-sized devices; the former means high $\mathrm{CO}_{2}$ emissions.

In contrast, crystalline silicon (c-Si) PV cells are promising candidates that can be combined with $\mathrm{EC}$ reactors considering the current worldwide spread of c-Si solar cells for solar PVs. A $\eta_{\text {STH }}$ of $14 \%$ was achieved based on the combination of three series-connected c-Si PV cells and an EC reactor using Ni-related catalysts with an active area of $1.3 \mathrm{~cm}^{2}{ }^{17}$. Therefore, c-Si PV-EC systems might be a solution to realize large-sized artificial photosynthetic cells with a $\eta_{\text {STC }}$ value of $10 \%$, which is the target value for practical use ${ }^{18}$.

However, the scale-up of EC reactors frequently lowers the $\eta_{\mathrm{STC}}$. Table 1 summarizes the performance of previously reported large-scale (area > $10 \mathrm{~cm}^{2}$ ) PEC ${ }^{19-21}, \mathrm{PV}-\mathrm{EC}^{22,23}$, and $\mathrm{PC}^{24}$ systems. The $\eta_{\mathrm{STH}}$ value of $3.9 \%$ obtained with the $64 \mathrm{~cm}^{2}$ system is significantly lower than that reported for the above-mentioned small-sized systems. One of the obstacles to the scale-up is that a larger electrode catalyst leads to a higher electric resistance, resulting in a potential drop. Another obstacle unique to $\mathrm{CO}_{2}$ reduction is that the $\mathrm{CO}_{2}$ supply to a large reaction area is insufficient because of an inhomogeneous flow of the electrolyte in which $\mathrm{CO}_{2}$ is dissolved. 
Table 1

Performance of the large-scale $\left(>10 \mathrm{~cm}^{2}\right.$ area) $\mathrm{PEC}^{19-21}, \mathrm{PV}+\mathrm{EC}^{22,23}$, and $\mathrm{PC}^{24}$ systems.

\begin{tabular}{|c|c|c|c|c|c|c|c|c|}
\hline Methods & Anode & Cathode & Product & $\begin{array}{l}\text { Rate of } \\
\text { product } \\
(\mathrm{mmol} / \mathrm{h})\end{array}$ & $\begin{array}{l}\text { Average } \\
\text { current } \\
\text { density } \\
\left(\mathrm{mA} / \mathrm{cm}^{2}\right)\end{array}$ & $\begin{array}{l}\text { Area of } \\
\text { irradiation } \\
\left(\mathrm{cm}^{2}\right)\end{array}$ & 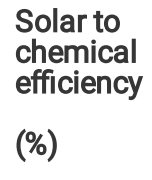 & Reference \\
\hline PEC cell & $\mathrm{FTO} / \mathrm{Fe}_{2} \mathrm{O}_{3}$ & $\mathrm{Ti} / \mathrm{Pt}$ & $\mathrm{H}_{2}$ & - & 0.45 & 50 & - & Ref. 19 \\
\hline $\begin{array}{l}\text { DSSC+ } \\
\text { photoanode }\end{array}$ & $\mathrm{FTO} / \mathrm{Ag} / \mathrm{WO}_{3}$ & $\mathrm{Pt}$ & $\mathrm{H}_{2}$ & 8.91 & 1.18 & 131 & 1.4 & Ref. 20 \\
\hline $\begin{array}{l}\text { Si PV + } \\
\text { photoanode }\end{array}$ & $\mathrm{W}: \mathrm{BiVO}_{4} / \mathrm{CoPi}$ & $\mathrm{Pt}$ & $\mathrm{H}_{2}$ & - & 1.7 & 50 & 2.1 & Ref. 21 \\
\hline 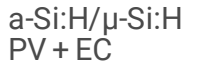 & $\mathrm{Ni}$ & $\mathrm{Ni}$ & $\mathrm{H}_{2}$ & 6.58 & 3.13 & 64 & 3.9 & Ref. 22 \\
\hline$c-S i P V+E C$ & IrOx & nanoporous Ag & $\mathrm{CO}$ & 1.54 & 6.5 & 14 & 8 & Ref. 23 \\
\hline $\begin{array}{l}\text { Photocatalysis } \\
\text { sheet }\end{array}$ & $\begin{array}{l}\mathrm{RhCrO}_{\mathrm{x}}+\mathrm{CoO}_{\mathrm{x}} / \\
\mathrm{Al}: \mathrm{SrTiO}_{3}\end{array}$ & & $\mathrm{H}_{2}$ & 39.2 & - & 9801 & 0.4 & Ref. 24 \\
\hline $\begin{array}{l}\text { c-Si PV + } \\
\text { stacked EC }\end{array}$ & $\mathrm{FTO} / \mathrm{Ag} / \mathrm{IrO}_{\mathrm{x}}$ & $\begin{array}{l}\text { Ti/graphite/CS/ } \\
\text { MWCNTs/RuCP }\end{array}$ & Formate & $93.5 \pm 2.4$ & $6.44 \pm 0.04$ & 973 & $7.2 \pm 0.18$ & This work \\
\hline
\end{tabular}

On the other hand, the photocatalytic (PC) system is one of the simplest methods for water splitting ${ }^{25-27}$ and $\mathrm{CO}_{2}$ reduction ${ }^{28,29}$. The advantages are lower fabrication costs and a simple scale-up process. A $\eta_{\mathrm{STH}}$ of $0.4 \%$ was achieved with a $1 \mathrm{~m}^{2}$ flat panel reactor using an Aldoped $\mathrm{SrTiO}_{3}$ photocatalyst ${ }^{24}$. In the PC system, both the photogeneration of electron-hole pairs and redox reaction occur within a single semiconductor material. Therefore, the electron-hole pairs rapidly recombine before they are used for the chemical reaction. Thus, the current maximum $\eta_{\mathrm{STH}}$ is $3.3 \%$, even for a small-sized cell ${ }^{25}$.

Here, we demonstrate the solar-driven reduction of $\mathrm{CO}_{2}$ to formate using a large artificial photosynthetic cell of the PV-EC type with an irradiation area of $\sim 1000 \mathrm{~cm}^{2}$. We achieved a $\eta_{\text {STC }}$ of $7.2 \%$ and the highest production rate reported for large cells (including $\mathrm{H}_{2}$ generation). Based on our concept, a high $\eta_{\text {STC }}$ and scale-up are balanced at a high level using a simple cell structure such that the present technology can be applied to further larger cells and mass production in the near future. For this purpose, we adopted an iridium oxide (IrO $)_{x}$ as an anode catalyst and a ruthenium complex polymer, that is, $\left[\mathrm{Ru}\left\{4,4^{\prime} \text {-di(1 } 1 \text {-pyrrolyl-3-propylcarbonate)2,2'-bipyridine }\right\}(\mathrm{CO})_{2}\right]_{\mathrm{n}}(\mathrm{RuCP})$, as a cathode catalyst. A low onset voltage can be achieved using this combination with a single-compartment EC reactor filled with a sole electrolyte at a near-neutral $\mathrm{pH}$, which is essential for a high $\eta_{\mathrm{STC}}{ }^{30,31}$ and simplifies the large-sized cell structure. Based on this material technology, we were able to address problems unique to the scale-up, that is, the development of low-resistivity large-sized electrode catalysts and a flow channel for homogeneous flow of the $\mathrm{CO}_{2}$-dissolved electrolyte between large-sized anodes and cathodes. We used printing, dip-coating, and drop-coating processes to fabricate large-sized electrode catalysts. These processes are suitable for low-cost mass production. The newly developed largesized EC reactor are connected to single-crystalline Si PV cells, which provide a higher conversion efficiency ${ }^{32}$ than amorphous Si PV cells that are often used for large-sized monolithic devices ${ }^{22}$. The EC reactor and PV cells are designed such that the photogenerated electrons in the PV cell are completely utilized for the EC reaction.

\section{Results}

\section{Design of large-sized artificial photosynthetic cells}

In a previous study, the use of a monolithic tablet-shaped device (Type A; Fig. 1a) with an active area of $1 \mathrm{~cm}^{2}$ yielded a formate production $\eta_{\mathrm{STC}}$ of $4.6 \%{ }^{31}$. The $\mathrm{IrO}_{x}$ water oxidation catalyst was loaded on the front surface (wider bandgap side) of a triple-junction amorphous silicongermanium PV cell, and RuCP supported by a carbon sheet (CS) coated with multi-walled carbon nanotubes (MWCNTs) ${ }^{30}$ was fixed as a CO $_{2}$ reduction catalyst on the back surface (narrower bandgap side). This combination of $\mathrm{IrO}_{x}$ and RuCP drives the $\mathrm{CO}_{2}$ reduction reaction in a potassium phosphate buffer $(\mathrm{KPi})$ aqueous solution $\left(\mathrm{pH} 6.3\right.$ at $0.4 \mathrm{M}$ with saturated $\mathrm{CO}_{2}$ ) at a low overvoltage without chemical bias. In contrast to most high-efficiency EC reactors, which require two-compartment reactors with membranes and strong-acid or -base electrolytes ${ }^{14}$ -

16 , leading to complex cell structures, our combination is of great advantage for the scale-up. Furthermore, the tablet-shaped structure does not lead to electric resistance problems, even when it is scaled-up. However, the diffusion path of the protons from the anode to the cathode in the 
electrolyte increases. This leads to a significant increase in the diffusion resistance, and hence it has been a matter of debate how large the tablet-shaped device can be used as a component of a large-sized cell ${ }^{31}$. Therefore, we evaluated the effect of the anode-cathode distance and observed that the current density at a given voltage significantly decreases with increasing distance (up to several tens of centimeters), as shown in Supplementary Fig. 1 . To make the large size compatible with a high $\eta_{S T C}$, we employed another structure (Type B), which is illustrated in Fig. 1b. The anodes and cathodes ( $1000 \mathrm{~cm}^{2}$ in size) face each other with a small distance of $1 \mathrm{~cm}$ in a transparent plastic housing and are directly connected to c-Si PV cells with similar sizes. Thus, the use of Type B solves the proton diffusion resistance problem. However, it leads to problems with respect to the electrode catalysts with low electric resistance and homogeneous flow of the electrolyte in the narrow gaps between the anodes and cathodes facing each other; solutions are described in the following subsections.

To achieve a high $\eta_{\mathrm{STC}}$, it is also important to match the PV performance with the EC activity. The active area of the electrode catalysts should be large enough such that the photoexcited electrons of the PV cells can be completely utilized for the reaction. However, a larger electrode size leads to a larger influence of the high electric resistance and insufficient $\mathrm{CO}_{2}$ supply. Therefore, we adopted stacked electrode catalysts that were electrically connected in parallel. A combination of five stacked electrodes and six series-connected c-Si PV cells was found to be optimal based on the evaluation of newly developed large-sized anodes and cathodes described in the following subsections. The large-sized cell used in PV-EC Type B is displayed in Fig. 2 and Supplementary Movie 1.

\section{Development Of Large-sized Anodes}

Anodes consisting of $\mathrm{Ti}$ substrate//rO ${ }_{x}$, which are commercially available (Anodec 100, Nisshin Kasei Co. Ltd.) have been utilized for water electrolysis under strong acidity ${ }^{33}$. On the other hand, it is known that $\mathrm{IrO}_{x}$ nanocolloids exhibit a high water oxidation activity over a wide $\mathrm{pH}$ range ${ }^{34}$. Therefore, we developed anodes using $\mathrm{IrO}_{x}$ nanocolloids and compared them with Anodec 100 to select suitable anode materials for the present $\mathrm{KPi}$ electrolyte with $\mathrm{pH}=6.3$ under $\mathrm{CO}_{2}$ saturation.

We used glass plates covered with F-doped $\mathrm{SnO}_{2}$ (FTO) layers as substrates, which were loaded with IrO $_{x}$ nanocolloids, because of their chemical stability. The $\mathrm{IrO}_{x}$ nanocolloids were synthesized according to a previous report ${ }^{31}$ and dropped and dried onto the FTO glass. The drop-dry processes were repeated two, four, and six times. The $\mathrm{IrO}_{x}$ nanocrystals were sparsely dispersed on the FTO glass (twice; Supplementary Fig. 2a). With increasing repeat count, the load amount of IrO $_{x}$ increased and the water oxidation activity improved (Supplementary Figs. $3 a$ and $3 b$, respectively). When the processes were repeated six times, the loaded area was completely covered with IrO $_{x}$ nanocrystals (Supplementary Fig. 2b).

The small-sized $\mathrm{FTO} / \mathrm{IrO}_{x}$ anode exhibited a higher catalytic activity than Anodec 100; the onset potential was lower and the current was larger, as shown in Supplementary Fig. 4. The current density was more than double that of Anodec 100 at a small overpotential. Another advantage of the $\mathrm{FTO} / \mathrm{IrO}_{x}$ anode is the high transmittance of $40-60 \%$ (Supplementary Fig. 5), which allows us to observe the reaction from the anode side under light irradiation (Supplementary Movie 1). Therefore, we adopted the $\mathrm{FTO} / \mathrm{IrO}_{x}$ anode.

However, the sheet resistance of the FTO glass is $10 \Omega$ /square, which causes a potential drop and thus deteriorates the water oxidation activity of the large-sized anode. In analogy with dye-sensitized solar cell (DSC) modules, which also use FTO glasses ${ }^{35-37}$, we formed Ag grid patterns on the FTO glasses to reduce the net sheet resistance. To prevent the Ag grids from corrosion by the electrolyte, the Ag grids were doublecovered with low-melting glass and epoxy resin coatings, as illustrated in Fig. 3a. The widths of Ag and cover glass as well as the distance between adjacent Ag grids were determined according to those of the DSC modules ${ }^{35-37}$.

The effect of the cover coatings was confirmed using model samples. The bare Ag grid was blackened by anodic polarization in the KPi electrolyte with a dramatic increase in the electric resistance, as shown in Supplementary Fig. 6. In contrast, the appearance or resistance did not change when the Ag grid was doubly covered.

\section{Development Of Large-sized Cathodes}

We optimized the amount of RuCP loaded in the CSs coated with MWCNTs. The CSs were dip-coated with MWCNTs. Subsequently, a mixed solution of the Ru complex, pyrrol, and $\mathrm{FeCl}_{3}$ in acetonitrile-ethanol was dropped onto the CS/MWCNTs and dried; the drop-dry processes were repeated ten times. The amount of RuCP in the CS/MWCNTs was controlled by adjusting the amount of the solution.

When 1.33 times the original amount $\left(1.86 \times 10^{-7} \mathrm{~mol} / \mathrm{cm}^{2}\right)$ of RuCP was loaded, most of the RuCP penetrated the CS/MWCNTs, as shown in the SEM images in Supplementary Fig. 7. This resulted in an increase in the amount of formate and an improvement in faradaic efficiency ( $F E$ ), as depicted in Supplementary Fig. 8. However, the addition of more RuCP lead to the deterioration of the performance. The excess RuCP did not 
penetrate the CS/MWCNTs, but formed a dense layer on the surface, which blocked the transport of protons, $\mathrm{CO}_{2}$, and/or formate. Thus, we adopted 1.33 times the original amount of RuCP to fabricate large-sized cathodes.

The requirements for the cathode substrates are a low catalytic activity for the $\mathrm{H}_{2}$ evolution reaction, low electric resistance, and chemical stability. The Ag grid/FTO glass plates developed for the anodes meet these requirements. Another candidate is a Ti plate. The CSs loaded with MWCNTs and RuCP were fixed on these two types of substrates with a graphite adhesive to complete the large-sized cathodes, as illustrated in Figs. $3 b$ and $3 c$, respectively.

\section{Design of the flow channel of the electrolyte by fluid simulation}

During the scale-up, it is important to ensure a homogeneous flow of the electrolyte to achieve a sufficient $\mathrm{CO}_{2}$ supply and rapid formate extraction. To identify the optimal structure of the flow channel, we carried out fluid simulations. The flow channel equipped with an orifice plate

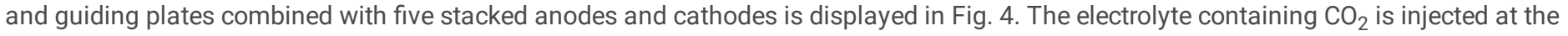
entrance at the lower face of the housing and dispensed via the orifice plate to each gap between the anode and cathode facing each other. Each gap is partitioned into seven rooms by guiding plates with small clearances connecting the neighboring rooms. Subsequently, it overflows and finally flows out of the exit at the bottom of the side face. The generated gases, including $\mathrm{O}_{2}$ and byproducts $\left(\mathrm{H}_{2}\right.$ and $\left.\mathrm{CO}\right)$, are diluted for safety and exhausted from the upper port. The overflow plate and gas-liquid separation also contribute to the homogeneous flow of the electrolyte.

We designed two orifice plate patterns with different orifice sizes: Orifices I and II. The details are described in Supplementary Fig. 9. We examined the flow rate distribution using SOLID WORKS Flow Simulation software. Figure 5 shows the results. Orifice I exhibits an extremely rapid flow in the room $4 \mathrm{C}$ immediately above the entrance and large flow rates in the other rooms in the gap $\mathrm{C}$, as is clear from Figs. $5 \mathrm{a}$ and $5 \mathrm{e}$. Instead, the flow rates in the other gaps are appreciably slower (Figs. $5 \mathrm{~b}$ and $5 \mathrm{e}$ ), which would result in a shortage of the $\mathrm{CO}_{2}$ supply. The standard deviation $(\sigma)$ of the flow rate at a distance of $30.9 \mathrm{~cm}$ from the orifice plate I is as large as $13 \%$ relative to the mean flow rate. In contrast, Orifice II with smaller orifices yields a homogeneous flow, leading to a small $\sigma$ value of $3.7 \%$. Thus, we adopted Orifice II for the largesized Type B cell.

\section{Matching Between EC Electrode Catalysts And PV Cells}

The operating current $\left(I_{\mathrm{op}}\right)$ and voltage $\left(V_{\mathrm{op}}\right)$, which are the values at the intersection of the current $(I)$-voltage $(V)$ curve of the PV cells and load curve of the EC reactor, must be close to the values at the maximum power of the PV cells. Otherwise, the photoexcited electrons and/or electron energies partially dissipate. To identify the optimal numbers of stacks of electrode catalysts and series connections of the c-Si PV cells, we measured linear sweep voltammetry (LSV) curves of the EC reactor consisting of a single pair of anode and cathode with the Ag grid/FTO glass plates using a potentiostat. Moreover, we obtained the $I-V$ curves of the four and six series-connected c-Si PV cells, which are both $\sim$ $1000 \mathrm{~cm}^{2}$ in size, under standard air mass (AM) 1.5G 1 sun irradiation using a solar simulator of class AAA.

Notably, the rated maximum power $\left(P_{\max }\right)$ of c-Si PV cells of $>18 \mathrm{~W}$ was measured at $25^{\circ} \mathrm{C}$ using a flush lamp according to the IEC61215-2 standard. However, in reality, these PV cells operate under continuous irradiation over several hours. Therefore, we acquired the $I-V$ data $1 \mathrm{~h}$ after the irradiation started. The measured $P_{\max }$ of 14-15 W and other PV parameters, except for the short-circuit current, were significantly lower than the rated values, as depicted in Fig. 6 and Supplementary Table 1, which is due to a temperature increase to $>60{ }^{\circ} \mathrm{C}^{38,39}$.

When a single pair of anode and cathode was combined with four series-connected c-Si PV cells, $I_{\text {op }}$ was $1.35 \mathrm{~A}, V_{\text {op }}$ was $2.29 \mathrm{~V}$, and the ratio of the power supplied to the electrode catalysts to $P_{\max }\left(I_{\mathrm{op}} \times V_{\mathrm{op}} / P_{\max }\right)$ was 0.22 . This means that the PV performance of the c-Si PV cells was largely wasted. Based on the assumption that the current of stacked electrode catalysts increases proportionally to the stack number, the use of five stacked electrodes that are electrically parallel-connected improves $I_{\text {op }} \times V_{\text {op }} / P_{\text {max }}$ to $0.66\left(I_{\text {op }}=4.41 \mathrm{~A}, V_{\text {op }}=2.10 \mathrm{~V}\right)$. When the electrodes are combined with six series-connected c-Si PV cells, $I_{\text {op }} \times V_{\text {op }} / P_{\max }$ further increases to $0.91\left(I_{\text {op }}=6.22 \mathrm{~A}, V_{\text {op }}=2.25 \mathrm{~V}\right)$. Thus, we adopted the combination of the five stacked electrode catalysts and six series-connected c-Si PV cells.

\section{Highly Efficient Solar-driven Co Reduction Using Stacked Electrode Catalysts}

We assembled the large-sized Type B cell using five stacked electrode catalysts, six series-connected c-Si PV cells, and Orifice II. We first confirmed that the measured LSV curve of the five stacked electrodes agrees with the estimated one, as shown in Fig. 7a. The $I_{\text {op }}, V_{\text {op }}$, and $I_{\text {op }} \times$ $V_{\mathrm{op}} / P_{\mathrm{max}}$ values were determined to be $6.26 \mathrm{~A}, 2.23 \mathrm{~V}$, and 0.91 , respectively, indicating a good match between the EC reactor and PV cells. 
We conducted solar-driven $\mathrm{CO}_{2}$ reduction measurements of Type $\mathrm{B}$ cell two times. Figure 7 shows the results for the first measurement. The cell operation was highly stable under 1 sun solar irradiation; both the current and voltage were almost constant for a total of $3 \mathrm{~h}$ of irradiation, as is clear from Figs. 7b and 7c, respectively. This results in the increases in the accumulated charge and concentration of formate proportional to the irradiation time depicted in Figs. $7 \mathrm{~d}$ and 7e, respectively. The resultant formate generation $\eta_{\mathrm{STC}}$ over the $3 \mathrm{~h}$ is $5.74 \%$. Similar results were exhibited in the second measurement. Considering that the accuracy of the measured concentration of formate in the electrolyte are $\pm 5 \%, \eta_{S T C}$ and and $F E$ of formate generation averaged over the two measurements and there accuracy are $\eta_{\mathrm{STC}}=5.7 \pm 0.15 \%$ and $F E=64 \pm 1.7 \%$. The $\eta_{\mathrm{STC}}$ exceeds that of the small-sized monolithic device ${ }^{31}$, as summarized in Table 2, despite the lower FE.

Table 2

Performance of the solar-driven $\mathrm{CO}_{2}$ reduction of large artificial photosynthetic cells developed in this study. The average values of $R \mathrm{~F}, F E$, current density and $\eta_{\mathrm{STC}}$ over the two measurements are shown.

\begin{tabular}{|c|c|c|c|c|c|c|c|c|c|}
\hline Structure & Anode & Cathode & $\begin{array}{l}\text { Irradiation } \\
\text { time } \\
\text { (h) }\end{array}$ & $\begin{array}{l}\text { Electric } \\
\text { charges } \\
\text { (C) }\end{array}$ & $\begin{array}{l}\text { Rate of } \\
\text { folmate } \\
\left(R_{\mathrm{F}}\right) \\
(\mathrm{mmol} / \mathrm{h})\end{array}$ & $\begin{array}{l}\text { Faradaic } \\
\text { Efficiency } \\
(F E)(\%)\end{array}$ & 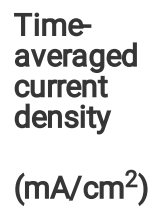 & $\begin{array}{l}\text { Area of } \\
\text { irradiation } \\
\left(\mathrm{cm}^{2}\right)\end{array}$ & $\begin{array}{l}\text { Solar to } \\
\text { folmate } \\
\text { efficiency } \\
\left(n_{\text {STC }}\right) \\
(\%)\end{array}$ \\
\hline $\begin{array}{l}\text { Single } \\
\text { small } \\
\text { monolitic } \\
\text { device } \\
\text { [Ref.31] }\end{array}$ & ITO/IrO & SiGe-PV/CC/RuCP & 3 & 18.4 & $\begin{array}{l}15.3 \times \\
10^{-3}\end{array}$ & 94 & 3.3 & 0.25 & 4.6 \\
\hline $\begin{array}{l}\text { Large } \\
\text { cell }\end{array}$ & $\mathrm{FTO} / \mathrm{Ag} / \mathrm{IrO}_{\mathrm{x}}$ & $\begin{array}{l}\text { FTO/Ag/graphite/ } \\
\text { CS/MWCNTs/RuCP }\end{array}$ & 3 & 66281 & $73.7 \pm 1.9$ & $64 \pm 1.7$ & $\begin{array}{l}6.43 \pm \\
0.13\end{array}$ & 973 & $\begin{array}{l}5.7 \pm \\
0.15\end{array}$ \\
\hline $\begin{array}{l}\text { Large } \\
\text { cell }\end{array}$ & $\mathrm{FTO} / \mathrm{Ag} / \mathrm{IrO}_{\mathrm{x}}$ & $\begin{array}{l}\text { Ti/graphite/ } \\
\text { CS/MWCNTs/RuCP }\end{array}$ & 3 & 67677 & $93.5 \pm 2.4$ & $80 \pm 2.0$ & $\begin{array}{l}6.44 \pm \\
0.04\end{array}$ & 973 & $\begin{array}{l}7.2 \pm \\
0.18\end{array}$ \\
\hline
\end{tabular}

Although Ag grid patterns were formed on the FTO glass plates, the electric resistivity was not low enough. This leads to a potential drop in a single electrode, which in turn decreases the current at a given applied voltage. Thus, we used Ti plates as cathode substrates instead of Ag grid/FTO glass plates. Figure $7 a$ shows that the LSV characteristics significantly improved using Ti plates. The $V_{\text {op }}$ decreased to $1.90 \mathrm{~V}$ with an $I_{\text {op }}$ value of $6.30 \mathrm{~A}$ that is close to $I_{\text {op }}$ of the Ag grid/FTO glass cathodes. Although $I_{\text {op }}$ barely changed under irradiation, the formate concentration significantly increased, leading to a higher $\eta_{\text {STC }}$ of $7.2 \pm 0.18 \%$ and $F E$ of $80 \pm 2.0 \%$.

Based on the comparison of the two cathodes using Ag grid/FTO glass and Ti plates, $V_{\text {op }}$ of the FTO glass cathodes is $0.45 \mathrm{~V}$ larger at approximately the same $I_{\text {op }}$. Therefore, the potential at the line-connecting terminals of the cathodes is higher and the potential drop is larger due to the electric resistivity. The higher potential promotes $\mathrm{H}_{2}$ and $\mathrm{CO}$ generation, as depicted in Supplementary Fig. 10, and hence lowers $F E$ of the formate production.

\section{Discussion}

In this study, we demonstrate a high-level balance between a high formate production $\eta_{\mathrm{STC}}$ of $7.2 \%$ and a large cell size $\left(\sim 1000 \mathrm{~cm}^{2}\right.$ active area), resulting in a large formate production rate of $93.5 \mathrm{mmol} / \mathrm{h}$. The high $\eta_{\mathrm{STC}}$ is due to the very low $V_{\text {op }}=1.90 \mathrm{~V}$ at $6.30 \mathrm{~A}$ (Fig. $7 \mathrm{a}$ ), which is outstanding compared with that reported for previous EC reactors generating liquid organic substances from $\mathrm{CO}_{2}$ in liquid phases. In the past, EC reactors equipped with gas diffusion electrode (GDL) catalysts have been used for the generation of CO and synthetic gas (syngas) 40,41 . The use of GDL catalysts greatly improves the throughput of the gaseous products by reducing the rate limit of the reaction arising from the diffusion of $\mathrm{CO}_{2}$ and products. However, the high $V_{\text {op }}$ required for a large throughput inevitably lowers the efficiency of the electricity-tochemical conversion proportional to $V_{0} / V_{\text {op }}$, where $V_{0}$ is the thermodynamic threshold voltage of the reaction, and consequently $\eta_{\text {STC. }}$ Based on our concept, the EC reactor is operated at a low $V_{\text {op }}$ to achieve a high $\eta_{S T C}$, which was realized using a RuCP cathode catalyst, low-resistive electrode substrates, sufficient $\mathrm{CO}_{2}$ supply, and good match between the PV cells and $\mathrm{EC}$ reactor. The mechanism underlying the very low onset potential close to the theoretical value $\left(-0.18 \mathrm{~V}\right.$ vs. RHE) for the $\mathrm{CO}_{2}$ reduction reaction using the RuCP loaded on CSs coated with $\mathrm{MWCNTs}$ in an aqueous solution was discussed previously ${ }^{30,31}$. Experiments and a density-functional calculation suggested that the onset potential of these complex catalysts with metal ion centers, such as $\mathrm{Ru}, \mathrm{Mn}, \mathrm{Co}$, and Re, coordinated with bipyridine ligands significantly decreases in the presence of $\mathrm{K}^{+}$cations, which provide a favorable environment to stabilize $\mathrm{CO}_{2}$ molecules adjacent to metal-bipyridine complexes ${ }^{42}$. 
On the other hand, the $\eta_{\text {STC }}$ must be further improved for practical use. To achieve the target value of $\eta_{\text {STC }}=10 \%{ }^{18}$, we would focus two points. We adopted c-Si PV cells because of their high-level balance between high conversion efficiency and low cost. However, the PV performance, in particular the open-circuit voltate and fill factor, remarkably decreases with increasing temperature under irradiation, as shown in

Supplementary Table 1. Solar cells connected to power conditioners always operate at the maximum power point despite temperature changes. In contrast, the operating point of PV cells directly connected to EC reactors deviates from the maximum power point depending on the temperature, which notably deteriorates the $\eta_{\mathrm{STC}}$. The operating temperature depends on the time-of-day and seasons. Heterojunction with intrinsic thin-layer $(\mathrm{HIT})^{38}$ and $\mathrm{Cu}(\mathrm{In}, \mathrm{Ga}) \mathrm{Se}_{2}$ (CIGS) $)^{39} \mathrm{PV}$ cells lead to smaller temperature coefficients of $-0.258 \% /{ }^{\circ} \mathrm{C}(\mathrm{HIT})$ and $-0.36 \% /{ }^{\circ} \mathrm{C}$ (CIGS) than $-0.45 \% /{ }^{\circ} \mathrm{C}$ of single crystalline Si PV cells. Therefore, the $\eta_{\text {STC }}$ can be improved and the annual production of formate can be increased by using these PV cells.

We first designed large-sized cells using FTO glass substrates. Although the Ag grid patterns significantly reduce the electric resistivity, we observed that there is room to improve the performance of the electrode catalysts by further reducing the resistivity by applying cathodes utilizing Ti substrates. However, Ti substrates used for Anodec 100 lower the catalytic activity of IrO ${ }_{x}$ in the KPi electrolyte. Denser Ag grid patterns on the FTO glass are not a solution because they reduce the active area. Therefore, another type of metal substrate and/or surface treatment are required for low-resistive anodes.

Finally, we estimated the plant scale for artificial photosynthetic $\mathrm{CO}_{2}$ recycling. From the viewpoint of collecting and recycling as many $\mathrm{CO}_{2}$ molecules as possible, it is more effective to use two-electron reduction products including formate than synthesizing larger organic molecules such as $\mathrm{C} 2$ compounds. If a machine factory with an area of 1 million m² would emit 50000 t $\mathrm{CO}_{2} / \mathrm{yr}^{2}$ in the near future ${ }^{43,44}$, which is significantly less than the present amount, artificial photosynthetic cells with a $\eta_{\mathrm{STC}}$ of $10 \%$ installed in $7 \%$ of the site would convert one-tenth of the $\mathrm{CO}_{2}$ emissions to $5230 \mathrm{t}$ formate/yr based on the assumption of an annual insolation of $1226 \mathrm{~kW} / \mathrm{m}^{2}$, as illustrated in Supplementary Fig. 11. Formate is a liquid hydrogen carrier with a high $\mathrm{H}_{2}$ density ${ }^{45}$, which is used for direct formic acid fuel cells ${ }^{46}$ and as raw material for chemical production ${ }^{47}$. The annual formate production is equivalent to $229 \mathrm{t} \mathrm{H}_{2} / \mathrm{yr}$, which fills $45800 \mathrm{H}_{2}$ tanks (5 kg/tank) of the fuel-cell vehicle MIRAI produced by the Toyota Motor Corporation. The large-sized artificial photosynthetic cells with a high $\eta_{\mathrm{STC}}$ demonstrated here open the door to a solar-driven $\mathrm{CO}_{2}$ recycling plant.

\section{Methods}

\section{Materials}

All material syntheses described in this subsection were carried out using pure water (> $18 \mathrm{M} \Omega \mathrm{cm}$ resistivity) prepared using Millipore Direct-Q system (Merck) in air-conditioned rooms at $22^{\circ} \mathrm{C}$.

Glass plates with a thickness of $4 \mathrm{~mm}$ covered with F-doped $\mathrm{SnO}_{2}$ (FTO) layers (sheet resistance of $10 \Omega$ /square, SA-25, Nippon Sheet Glass Co., Ltd.) were used as anode and cathode substrates. Ti plates with a thickness of $1 \mathrm{~mm}$ (sheet resistance of $\sim 0.14 \mathrm{~m} \Omega /$ square, TP270, Hakudo Co., Ltd.) were also used as cathodes. A silver paste (NP4508A1, Noritake Co., Ltd.) and low-melting glass paste (NP7007A1, Noritake Co., Ltd.) were used for the screen printing of the Ag grid patterns and primary cover coating of the Ag grids, respectively. Epoxy resin (DP 460 O/WHI, 3M, USA) was used for the secondary cover coating.

An $\mathrm{IrO}_{x}$ nanocolloid solution was prepared according to a previous report ${ }^{31}$, except that threefold amounts of all raw materials were put in a beaker to scale-up the synthesis. The scheme is summarized in Supplementary Fig. 12a. The $\mathrm{K}_{2} \mathrm{IrCl}_{6}$ (Fujifilm Wako Pure Chemical Co.), NaOH (Fujifilm Wako Pure Chemical Co.), and nitric acid (69 vol.\%, Fujifilm Wako Pure Chemical Co.) were used as received. It was confirmed that the catalytic activity of the nanocolloids synthesized using the present scale-up process was close to that of the original process. Supplementary Fig. 12b shows that the two LSV curves of the small-sized anodes prepared using these two processes agree with each other. An Anodec 100 $\left(\mathrm{Ti} / \mathrm{IrO}_{x}\right)$ was purchased from Nissinkasei Co., Ltd., Japan.

The RuCP was prepared according to a previous method ${ }^{31}$. The $\left[\mathrm{Ru}\left\{4,4^{\prime}-\mathrm{di}(1-\mathrm{H}-1\right.\right.$-pyrrolypropyl carbonate)-2,2'-bipyridine $\left.\}(\mathrm{CO}){ }_{2} \mathrm{Cl}_{2}\right]\left(\mathrm{Ru}^{\mathrm{B}} \mathrm{CO}\right)$ complex was synthesized using a previously reported method ${ }^{48}$. The original composition of the RuCP solution was as follows: Ru complex $\left(1.86 \times 10^{-7} \mathrm{~mol} / \mathrm{cm}^{2}\right)$, pyrrol $\left(7.33 \times 10^{-8} \mathrm{~mol} / \mathrm{cm}^{2}\right), \mathrm{FeCl}_{3}\left(1.12 \times 10^{-6} \mathrm{~mol} / \mathrm{cm}^{2}\right)$, ethanol $\left(0.11 \mathrm{~mL} / \mathrm{cm}^{2}\right)$, and acetonitrile $\left(0.353 \mathrm{~mL} / \mathrm{cm}^{2}\right)$. Pyrrol (Kanto Chemical Co., Inc.), iron(III) chloride hexahydrate $\left(\mathrm{FeCl}_{3} \cdot 6 \mathrm{H}_{2} \mathrm{O}, 99.9 \%\right.$, Wako), ethanol (Fujifilm Wako Pure Chemical Co.), and acetonitrile (Fujifilm Wako Pure Chemical Co.) were used as received. A 5 wt.\% MWCNT dispersion ink (Meijo Nano Carbon Co. Ltd.) and carbon sheets (CSs; TGP-H-060, Toray Industries, Inc.) were used as supports of the RuCP. A graphite adhesive (\#15-1137, Okenshoji Co., Ltd.) was used to fix the CS/MWCNT/RuCPs on the Ag grid/FTO glass and Ti plates. 
The 0.4 M KPi solution used as electrolyte was prepared using potassium phosphate $\left(\mathrm{K}_{2} \mathrm{HPO}_{4}: \mathrm{KH}_{2} \mathrm{PO}_{4}=1: 1 ;\right.$ Fujifilm Wako Pure Chemical Co. and pure water.

\section{Preparation Of Large-sized Electrode Catalysts}

The fabrication process of the large anodes is shown in Supplementary Fig. 13. First, Ag grid patterns consisting of finger and busbar electrodes were formed by screen printing of the Ag paste, followed by annealing at $400{ }^{\circ} \mathrm{C}$. Next, the primary cover coatings were fabricated by screen printing of the low-melting glass paste and post-annealing at $400{ }^{\circ} \mathrm{C}$. After covering the busbar electrodes with the epoxy resin and masking the finger Ag grid/glass coating to prevent corrosion, a series of $\mathrm{IrO}_{x}$ nanocolloid dropping, rinsing, and drying processes was repeated six times. Finally, secondary cover coatings of the epoxy resin were formed on the finger electrodes.

Large cathodes were fabricated using the following processes. The large CSs $(18 \mathrm{~cm} \cdot 20 \mathrm{~cm})$ were dipped into the MWCNT ink using a dip coater and dried, as shown in Supplementary Fig. 14. These processes were repeated two times. Subsequently, the CS/MWCNTs were annealed at $350{ }^{\circ} \mathrm{C}$ in an $\mathrm{Ar}$ atmosphere. Next, the RuCP solution was dropped onto the CS/MWCNTs cut into $16 \mathrm{~cm}$ square and the solvent was evaporated using a vacuum vessel, dry pump, and warm air outside the vessel. The apparatus is illustrated in Supplementary Fig. 15. These drop-evaporation processes were repeated ten times. The resultant CS/MWCNT/RuCPs were then dried at $60{ }^{\circ} \mathrm{C}$ for 30 min and placed in the dark at room temperature overnight. Finally, they were rinsed in pure water to remove $\mathrm{FeCl}_{3}$, followed by drying at $60{ }^{\circ} \mathrm{C}$ for 90 min. To complete the large-sized cathodes, four sheets of the CS/MWCNT/RuCPs were fixed on the substrate using the graphite adhesive. Two types of substrates, that is, Ag grid/FTO glass and Ti plates, were used.

\section{Material Characterization}

The amount of $\mathrm{IrO}_{X}$ loaded on the FTO glass substrates was determined with X-ray fluorescence analysis (XRF, ZSX Primus 2, RIGAKU). The calibration plot was obtained using standard samples with different Ir amounts. A scanning electron microscope (SEM, SU3500, Hitachi HighTechnologies Co.) was used to observe the $\mathrm{IrO}_{x}$ nanocrystals on the FTO glass plates and CS/MWCNTs/RuCPs. Transmittance spectra of the FTO//rO ${ }_{x}$ and Anodec 100 were measured using a spectroscopic ellipsometer (M2000, J. A. Woolam Co.) in transmission mode.

\section{Fluid Simulation Of The Electrolyte}

The flow rate distributions of the electrolyte for the two orifice patterns (Orifice I and Orifice II shown in Supplementary Fig. 9) were simulated using SOLID WORKS Flow Simulation software (Dassault Systèmes).

The electrolyte was injected at the entrance at a flow rate of $2 \mathrm{~L} / \mathrm{min}$. The pressure at the exit was set to the atmospheric pressure. The seven rooms separated by the guiding plates were numbered 1-7 and the five gaps between the anodes and cathodes facing each other were labeled A-E, as shown in Fig. 4 and Fig. 5.

\section{Electrochemical Measurements}

A potentiostat (VSP300, Bio-Logic Sciences Instruments) was used for the EC measurements. For typical EC experiments of small-sized electrode catalysts (active area of $1 \mathrm{~cm}^{2}$ ), a three-electrode configuration was adopted with a platinum counter electrode and $\mathrm{Ag} / \mathrm{AgCl}$ and $\mathrm{Hg} / \mathrm{Hg}_{2} \mathrm{SO}_{4}$ reference electrodes as anodes and cathodes, respectively. A potassium phosphate buffer (KPi) aqueous solution ( $\mathrm{pH} 6.3 \mathrm{with}$ saturated $\mathrm{CO}_{2}$ and concentration of $0.4 \mathrm{M}$ ) was used as electrolyte. The $\mathrm{CO}_{2}$ gas was bubbled into the electrolyte at a flow rate of $20 \mathrm{~mL} / \mathrm{min}$ for 20 min prior to and during the measurements. Linear sweep voltammetry (LSV) at a scan rate of $2 \mathrm{mV} / \mathrm{s}$, cyclic voltammetry (CV) at $10 \mathrm{mV} / \mathrm{s}$, and current $(I)$-time $(t)$ measurements at a constant potential mode were conducted. The potential relative to the reference electrodes was converted to the value vs. reversible hydrogen electrode (RHE) form using the following equations:

$E($ vs. $\mathrm{RHE})=E a+0.059 \mathrm{~V} \cdot \mathrm{pH}+0.199 \mathrm{~V}($ for $\mathrm{Ag} / \mathrm{AgCl})$,

$E($ vs. RHE $)=E a+0.059 \mathrm{~V} \cdot \mathrm{pH}+0.635 \mathrm{~V}($ for $\mathrm{Hg} / \mathrm{Hg} 2 \mathrm{SO} 4)$

where Ea is the applied potential.

The LSV was also conducted for the large-sized EC reactors of Type B equipped with a single anode-cathode pair and five stacked electrode catalysts. The $\mathrm{CO}_{2}$ gas was bubbled into the electrolyte in the tank at a flow rate of $100 \mathrm{~mL} / \mathrm{min}$ for more than $1 \mathrm{~h}$ before and during the measurements. 


\section{Solar-driven Co Reduction Measurements}

Two types of single crystalline Si PV modules (Chemitox Inc.) consisting of four and six series-connected cells with total active areas of 983 and $973 \mathrm{~cm}^{2}$, respectively, were used. The $I-V$ characteristics of these c-Si PV modules under irradiation were measured using a potentiostat (VSP300, Bio-Logic Sciences Instruments) with two-electrode configuration. The solar simulator (Model WSX-500-20 × 4, AM1.5G, Wacom Electric Co.) has an irradiation area of $50 \mathrm{~cm} \cdot 50 \mathrm{~cm}$ and air mass (AM) $1.5 \mathrm{G} 1$ sun spectral intensity of class AAA, as shown in Supplementary Fig. 16. The conversion efficiency $\left(\eta_{\mathrm{pv}}\right)$ and maximum output power $\left(P_{\mathrm{max}}\right)$ of the PV cells can be described as follows:

$\eta_{\mathrm{pv}}=I_{\mathrm{sc}} \times V_{\mathrm{oc}} \times F F / \mathrm{A}_{\mathrm{pv}} \times 100$

$P_{\max }=I_{\mathrm{pm}} \times V_{\mathrm{pm}}$

where $I_{\mathrm{sc}}$ is the short-circuit current, $V_{\mathrm{oc}}$ is the open-circuit voltage, $F F$ is the fill factor, $\mathrm{A}_{\mathrm{pv}}$ is the irradiation area (active PV area), $I_{\mathrm{pm}}$ is the current at $P_{\text {max }}$ and $V_{\mathrm{pm}}$ is the voltage at $P_{\text {max }}$. The PV performance is summarized in Supplementary Table 1 together with the data sheets according to the IEC61215-2 standard provided by the manufacturer.

The six series-connected PV cells were combined with the five stacked electrode catalysts to fabricate the Type B cell. The electrolyte in which $\mathrm{CO}_{2}$ was dissolved had a constant flow rate of $2 \mathrm{~L} / \mathrm{min}$. The $l-t$ and $V-t$ data of the cell under irradiation were acquired using a data logger.

The formate concentration was measured every 30 min or $1 \mathrm{~h}$. The irradiation was stopped once while the electrolyte flow was maintained for > $30 \mathrm{~min}$ such that the formate concentration in the electrolyte became uniform. Subsequently, the formate concentration in a small amount of the electrolyte sample was measured with an ion chromatograph (Integrion RFIC EG equipped with lonPac EGC-500-KOH, CR-ATC600 columns and a conductometric detector, Dionex Corporation). The calibration curve was obtained using formate aqueous solutions prepared at different concentrations $(0.01,0.1,0.2$, and $0.3 \mathrm{mM})$ prior to every measurement. The accuracy of the measured data was $\pm 5 \%$. The reduction of $\mathrm{CO}_{2}$ to formate and faradaic efficiency $(F E)$ of formate production were calculated as follows:

$\mathrm{CO}_{2}+2 \mathrm{H}^{+}+2 \mathrm{e}^{-} \rightarrow \mathrm{HCOOH}$

$F E=A F \times 2 /(C / F) \times 100$,

where $A F$ is the formate concentration (mol), $C$ is the charge $(C)$, and $F$ is the Faraday constant $(96485.3365 \mathrm{C} / \mathrm{mol})$.

The composition of the exhaust gas, including $\mathrm{CO}, \mathrm{H}_{2}, \mathrm{O}_{2}, \mathrm{~N}_{2}$, and $\mathrm{CO}_{2}$, was determined during the irradiation using a gas chromatograph (GC2014 , Shimadzu Co.). The calibration was conducted using two types of standard gases, that is, $\mathrm{A}\left(1.99 \mathrm{vol}^{\circ} \% \mathrm{H}_{2}, 2.02 \mathrm{vol}^{\circ} \% \mathrm{CO}_{2}, \mathrm{~N}_{2}\right.$ balance) and $\mathrm{B}$ (2.01 vol.\% CO, 2.04 vol. \% $\mathrm{CH}_{4}, 1.99$ vol.\% $\mathrm{C}_{2} \mathrm{H}_{6}, \mathrm{~N}_{2}$-balance), and air (79 vol.\% $\mathrm{N}_{2}, 21$ vol.\% $\mathrm{O}_{2}$ ).

The $\eta_{\mathrm{STC}}$ value of the formate production was calculated as follows:

$\eta_{\mathrm{STC}}=(R \mathrm{~F} \times \Delta \mathrm{G}) /\left(I_{\mathrm{solar}} \times \mathrm{A}_{\mathrm{pv}}\right) \times 100(\%)$,

where $R \mathrm{~F}$ is the mean rate of formate production, $\Delta \mathrm{G}$ is the change in the Gibbs free energy per mole of formate produced from CO2 and water $(\Delta \mathrm{G}=270 \mathrm{~kJ} / \mathrm{mol}$ at $298 \mathrm{~K})$, $I_{\text {solar }}$ is the solar irradiation intensity $\left(100 \mathrm{~mW} / \mathrm{cm}^{2}\right)$, and $A_{p v}$ is the irradiation area (active $P V$ area).

The mean rate of formate production $(R F)$ was determined from the slope of the fitting line for the formate production plots $>3 \mathrm{~h}$, as shown in Fig. 7e. When cathodes using Ti substrates were applied, the $\eta_{\mathrm{STC}}$ of the first measurement was calculated as follows:

$R \mathrm{~F} \cdot \Delta \mathrm{G}=93.5 \mathrm{mmol} / \mathrm{h} \cdot 270 \mathrm{~kJ} / \mathrm{mol}=93.5 \cdot 1000 / 3600 \cdot 270 \mathrm{~kJ} / \mathrm{mol}=7013 \mathrm{~mW}$

$I_{\text {solar }} \times A_{p v}=100 \mathrm{~mW} / \mathrm{cm}^{2} \cdot 975 \mathrm{~cm}^{2}=97500 \mathrm{~mW}, \eta_{\text {STC }}=7013 / 97500 \cdot 100=7.2 \%$

\section{Declarations}

\section{Data Availability}

The data supporting our findings of this study are available in the article and Supplementary Information file. All other relevant data are available on request from the authors.

\section{Author contributions}


N.K. designed the concept and supervised the experiments; S.M. configured the cell structure and measured the performance of the large cells; M.S., Y.K., and K.F. developed the large-sized electrode catalysts; N.N. designed the housing of the cells and flow channels; and T.M. and Y.T. designed the basic concept of the PV-EC connection. All authors performed the experiments and participated in the discussion.

\section{Acknowledgements}

We are grateful to K. Yamanaka, Y. Kikuzawa, H. Wakayama, K. Kurazono, T. Fukano, T. Ito, Y. Sakamoto, T. Arai, S. Sato, M. Kondo, T. Ozawa, K. Okuda, and $\mathrm{H}$. Yoshida for their contributions to this work. We also thank M. Iwai and K. Kitazumi for the material characterization as well as T. Tanaka and T. Shimazu for helpful comments and support.

\section{References}

1. Archer, D. Global Warming: Understanding The Forecast (Wiley-VCH Verlag GmbH \& Co. KGaA, Weinheim, 2nd ed., 2011).

2. Looney, B. Full report - BP statistical review of world energy 2020 (BP p.I.c, London, 69th ed. 2020).

3. Marshall, J. Solar energy: springtime for the artificial leaf. Nature 510, 22-24 (2014).

4. Kim, J. H., Hansora, D., Sharma, P., Jang, J.-W. \& Lee, J. S. Toward practical solar hydrogen production - an artificial photosynthetic leaf-tofarm challenge. Chem. Soc. Rev. 48, 1908 (2019).

5. Wu, J., Huang, Y., Ye, W. \& Li, Y. $\mathrm{CO}_{2}$ reduction: from the electrochemical to photochemical approach. Adv. Sci. 4, 1700194 (2017).

6. Sathre, R. et al. Life-cycle net energy assessment of large-scale hydrogen production via photoelectrochemical water splitting. Energy Environ. Sci. 7, 3264 (2014).

7. Cox, C. R., Lee, J. Z., Nocera, D. G. \& Buonassisi, T. Ten-percent solar-to-fuel conversion with nonprecious materials. Proc. Natl. Acad. Sci. 111, 14057-14061 (2014).

8. Schuttauf, J.-W. et al. Solar-to-hydrogen production at $14.2 \%$ efficiency with silicon photovoltaics and earth-abundant electrocatalysts. J. Electrochem. Soc. 163, F1177-F1181(2016).

9. Reece, S. Y. et al. Wireless solar water splitting using silicon-based semiconductors and earth-abundant catalysts. Science 334,645 (2011).

10. Park, H. et al. Water splitting exceeding 17\% solar-to-hydrogen conversion efficiency using solution-processed Ni-based electrocatalysts and perovskite/Si tandem solar cell. ACS Appl. Mater. Interfaces 11, 33835-33843 (2019).

11. Kobayashi, H. et al. Development of highly efficient Culn ${ }_{0.5} \mathrm{Ga}_{0.5} \mathrm{Se}_{2}$-based photocathode and application to overall solar driven water splitting. Energy Environ. Sci. 11, 3003-3009 (2018)

12. Kang, D. et al. Printed assemblies of GaAs photoelectrodes with decoupled optical and reactive interfaces for unassisted solar water splitting. Nat. Energy 2, 17043 (2017).

13. Pan, L. et al. Boosting the performance of $\mathrm{Cu}_{2} \mathrm{O}$ photocathodes for unassisted solar water splitting devices. Nat. Cat. 1, 412-420 (2018).

14. Jia, J. et al. Solar water splitting by photovoltaic-electrolysis with a solar-to-hydrogen efficiency over 30\%. Nat. Commun. 7, 13237 (2016).

15. Schreier, M. et al. Solar conversion of $\mathrm{CO}_{2}$ to $\mathrm{CO}$ using earth-abundant electrocatalysts prepared by atomic layer modification of CuO. Nat. Energy 2, 17087 (2017).

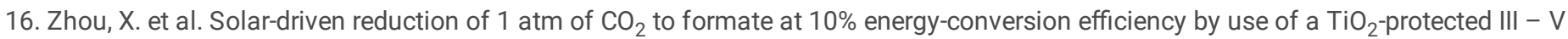
tandem photoanode in conjunction with a bipolar membrane and a Pd/C cathode. ACS Energy Lett. 1, 764-770 (2016).

17. Schuttauf, J.-W. et al. Solar-to-hydrogen production at $14.2 \%$ efficiency with silicon photovoltaics and earth-abundant electrocatalysts. J. Electrochem. Soc. 163, F1177 (2016).

18. Setoyama, T., Takewaki, T., Domen, K. \& Tatsumi, T. The challenges of solar hydrogen in chemical industry: how to provide, and how to apply? Faraday Discuss. 198, 509-527 (2017).

19. Vilanova, A., Lopes, T., Spenke, C., Wullenkord, M. \& Mendes, A. Optimized photoelectrochemical tandem cell for solar water splitting Energy Storage Materials 13, 175-188 (2018).

20. Lee, W. J., Shinde, P. S., Go, G. H. \& Ramasamy, E. Ag grid induced photocurrent enhancement in $\mathrm{WO}_{3}$ photoanodes and their scale-up performance toward photoelectrochemical $\mathrm{H}_{2}$ generation. Int. J. Hydrog. Energy 36, 5262-5270 (2011).

21. Ahmet, I. Y. et al. Demonstration of a $50 \mathrm{~cm}^{2} \mathrm{BiVO}_{4}$ tandem photoelectrochemical-photovoltaic water splitting device. Sustain. Energy Fuels 3, 2366-2379 (2019).

22. Turan, B. et al. Upscaling of integrated photoelectrochemical water-splitting devices to large areas. Nat. Commun. 7, 12681 (2016).

23. Chae, S. Y. et al. A perspective on practical solar to carbon monoxide production devices with economic evaluation. Sustain. Energ. Fuel. 4, 199-212 (2020). 
24. Goto, Y. et al. A particulate photocatalyst water-splitting panel for large-scale solar hydrogen generation. Joule 2, 509-520 (2018).

25. Chowdhury, F. A. et al. A photochemical diode artificial photosynthesis system for unassisted high efficiency overall pure water splitting. Nat. Commun. 9, 1707 (2018).

26. Maeda, K. et al. Photocatalytic overall water splitting promoted by two different cocatalysts for hydrogen and oxygen evolution under visible light. Angew. Chem. Int. Ed. 49, 4096-4099 (2010).

27. Chen, S. et al. Efficient visible-light-driven Z-scheme overall water splitting using a $\mathrm{MgTa}_{2} \mathrm{O}_{6}-{ }_{x} \mathrm{~N}_{y} /$ TaON heterostructure photocatalyst for $\mathrm{H}_{2}$ evolution. Angew. Chem. Int. Ed. 54, 8498-8501 (2015).

28. Sato, S., Morikawa, T., Saeki, S., Kajino, T. \& Motohiro, T. Visible-light-induced selective $\mathrm{CO}_{2}$ reduction utilizing a ruthenium complex electrocatalyst linked to a p-type nitrogen-doped $\mathrm{Ta}_{2} \mathrm{O}_{5}$ semiconductor. Angew. Chem. Int. Ed. 49, 5101-5105 (2010).

29. Yamazaki, Y., Takeda, H. \& Ishitani, O. Photocatalytic reduction of $\mathrm{CO}_{2}$ using metal complexes. J. of Photochem. Photobiol. C: Photochem. Rev. 25, 106-137(2015).

30. Sato, S., Arai, T. \& Morikawa, T. Electrocatalytic $\mathrm{CO}_{2}$ reduction near the theoretical potential in water using Ru complex supported on carbon nanotubes. Nanotechnology 29, 034001 (2018).

31. Arai, T., Sato, S. \& Morikawa, T. A monolithic device for $\mathrm{CO}_{2}$ photoreduction to generate liquid organic substances in a single-compartment reactor. Energy Environ. Sci. 8, 1998-2002 (2015).

32. Green, M. A. et al. Solar cell efficiency tables (version 52). Prog. Photovolt. Res. Appl. 26, 427-436 (2018).

33. $\mathrm{Hu}$, J. Z. et al. Stable Ti//rO ${ }_{2}$ Anode with Iridium-Titanium Oxide Interlayers for $\mathrm{O}_{2}$ Evolution. Materials Science Forum. $694,662-666$ (2011). doi:10.4028/www.scientific.net/msf.694.662.

34. Zhao, Y., Hernandez-Pagan, E. A., Vargas-Barbosa, N. M., Dysart, J. L. \& Mallouk, T. E. A high yield synthesis of ligand-free iridium oxide nanoparticles with high electrocatalytic activity. J. Phys. Chem. Lett. 2, 402-406 (2011).

35. Toyoda, T. et al. Outdoor performance of large-scale DSC modules. J. of Photochem. and Photobio. A: Chem. 164, 203-207 (2004).

36. Kato, N. et al. Degradation analysis of dye-sensitized solar cell module after long-term stability test under outdoor working condition. Sol. Energy Mater. Sol. Cells. 93, 893-897 (2009).

37. Zhang, Y-D. et al. How to design dye-sensitized solar cell modules. Sol. Energy Mater. Sol. Cells. 95, 2564-2569 (2011).

38. Mishima, T., et al. Development status of high-efficiency HIT solar cells. Sol. Energy Mater. Sol. Cells. 95, 18-21(2011). http://dx.doi.org/10.1016/j.solmat.2010.04.030.

39. 10.4229/25thEUPVSEC2010-4AV.3.83

Virtuani, A., Pavanello, D. \& Friesen, G. Overview of temperature coefficients of different thin film photovoltaic technologies. 25th European Photovoltaic Solar Energy Conference and Exhibition/5th World Conference on Photovoltaic Energy Conversion. 4248-4252 (2010). doi: 10.4229/25thEUPVSEC2010-4AV.3.83.

40. Haas, T. et al. Technical photosynthesis involving $\mathrm{CO}_{2}$ electrolysis and fermentation. Nat. Catal. 1, 32-39 (2018).

41. Ren, S. et al. Molecular electrocatalysts can mediate fast, selective $\mathrm{CO}_{2}$ reduction in a flow cell. Science 26, 367-369 (2019).

42. Sato, S., Saita, K., Sekizawa, K., Maeda, S. \& Morikawa, T. Low-energy electrocatalytic $\mathrm{CO}_{2}$ reduction in water over Mn-complex catalyst electrode aided by a nanocarbon support and $\mathrm{K}^{+}$cations. ACS Catal. 8, 5, 4452-4458 (2018).

43. Toyoda, A. et al. Toyota Motor Corporation Site Data Plant and Work Site Environment Data FY2019 Results (Toyota Motor Corp., Toyota City, 2020). https://global.toyota/pages/global_toyota/sustainability/esg/sitedata18_full_en.pdf (2020).

44. Toyoda, A. et al. Environmental Report 2019 -Toward the Toyota Environmental Challenge 2050-(Toyota Motor Corp., Toyota City, 2020). https://global.toyota/pages/global_toyota/sustainability/report/er/er19_en.pdf (2020).

45. Hull, J. et al. Reversible hydrogen storage using $\mathrm{CO}_{2}$ and a proton-switchable iridium catalyst in aqueous media under mild temperatures and pressures. Nat. Chem. 4, 383-388 (2012).

46. Jiang, J. \& Wieckowski, A. Prospective direct formate fuel cell. Electrochem. Commun. 18, 41-43 (2012).

47. Leitner, W. Carbon dioxide as a raw material: the synthesis of formic acid and its derivatives from $\mathrm{CO}_{2}$. Angew. Chem. Int. Ed. 34, 22072221(1995).

48. Sato, $\mathrm{S}$. et al. Selective $\mathrm{CO}_{2}$ conversion to formate conjugated with $\mathrm{H}_{2} \mathrm{O}$ oxidation utilizing semiconductor/complex hybrid photocatalysts. J. Am. Chem. Soc., 133, 15240-15243 (2011).

\section{Figures}


a

Type A

Single small

monolithic device

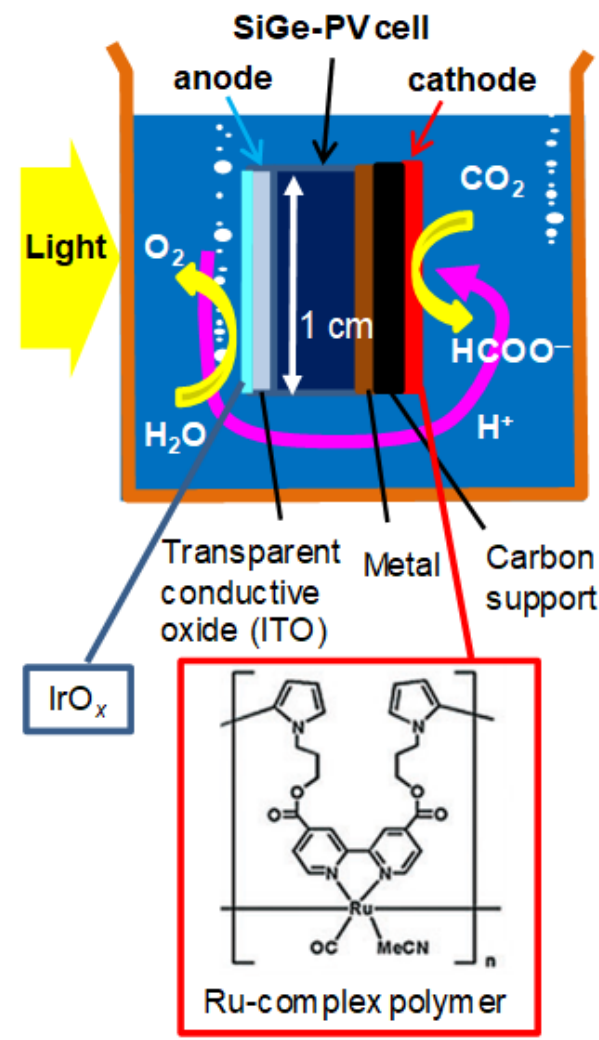

b Type B

Large-sized five stacked electrode catalysts

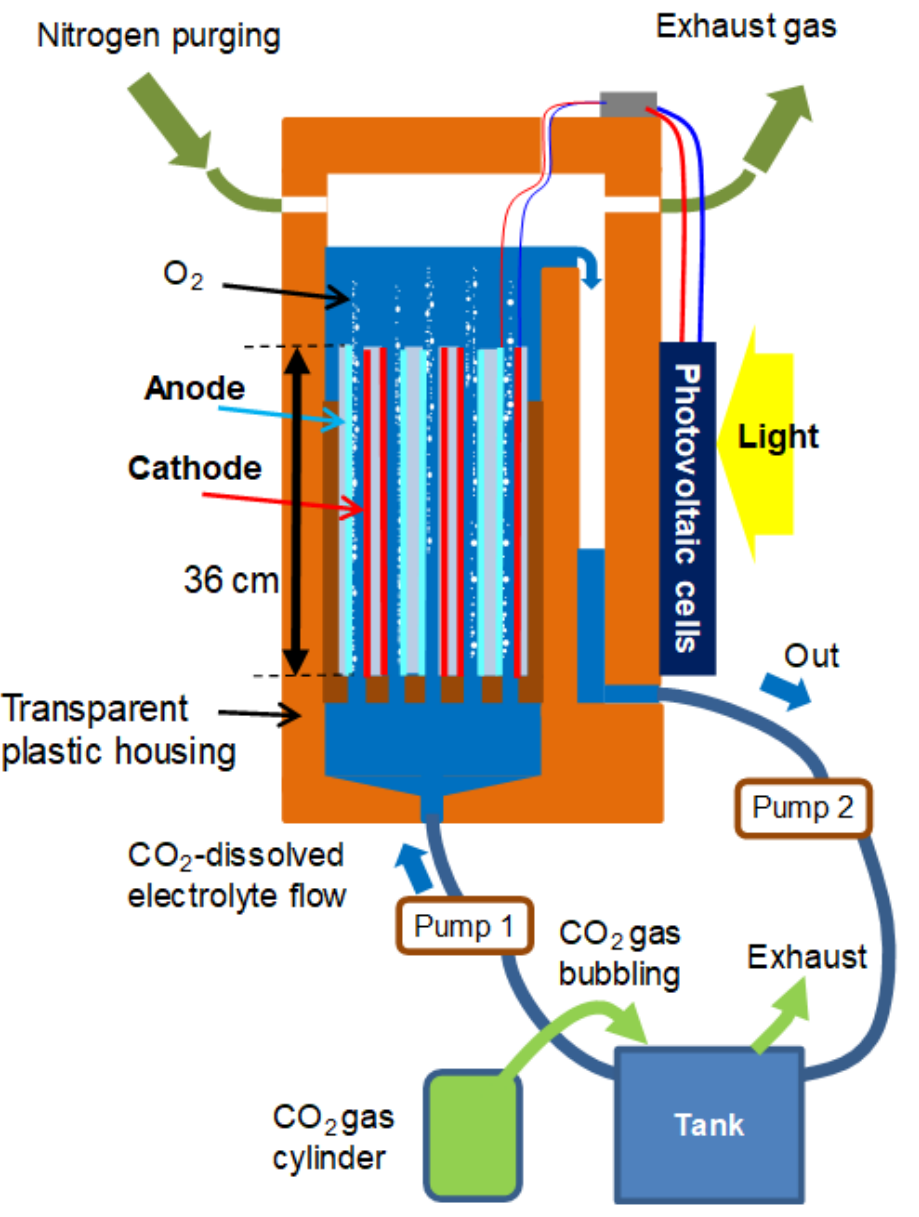

Figure 1

Two structures of artificial photosynthetic cells. a single small monolithic device (Type A), and b large-sized cell with stacked electrode catalysts (Type B). 


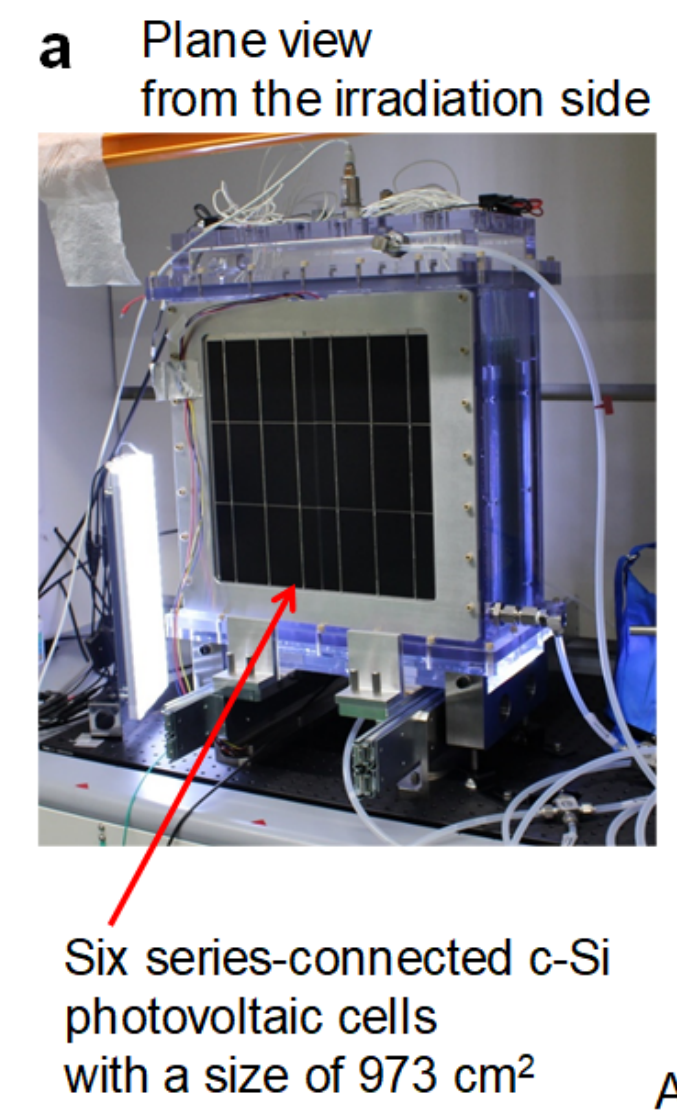

\section{b Side view}

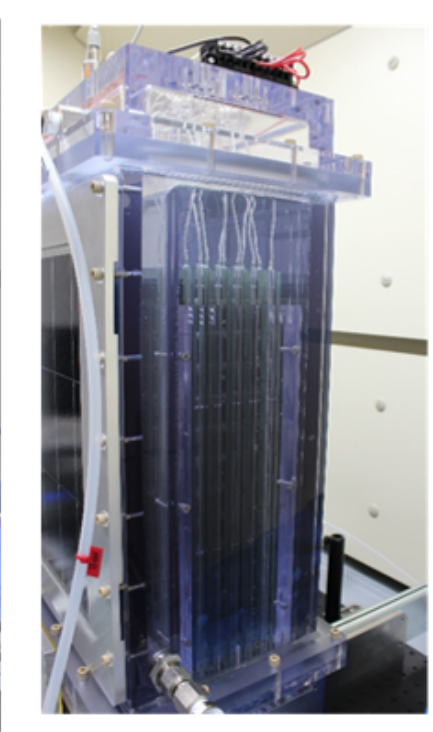

Ag/glass/resin grids
C Plane view from the back side in the dark

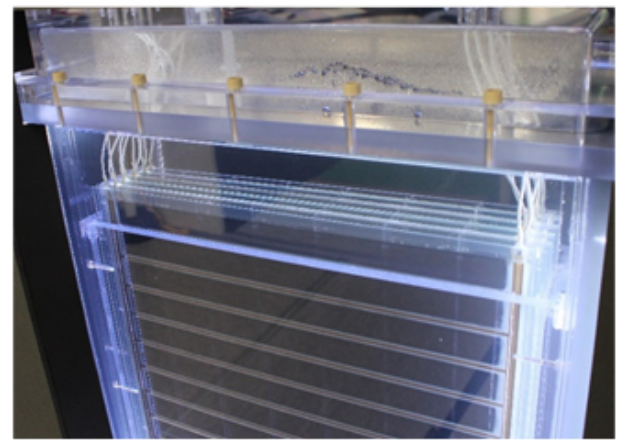

Under irradiation

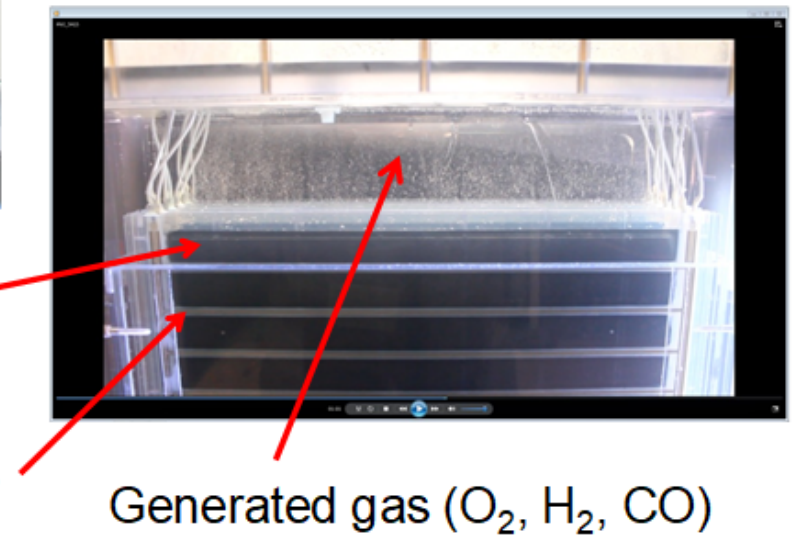

Figure 2

Photographs of the large artificial photosynthetic cell of Type B with stacked electrode catalysts. 


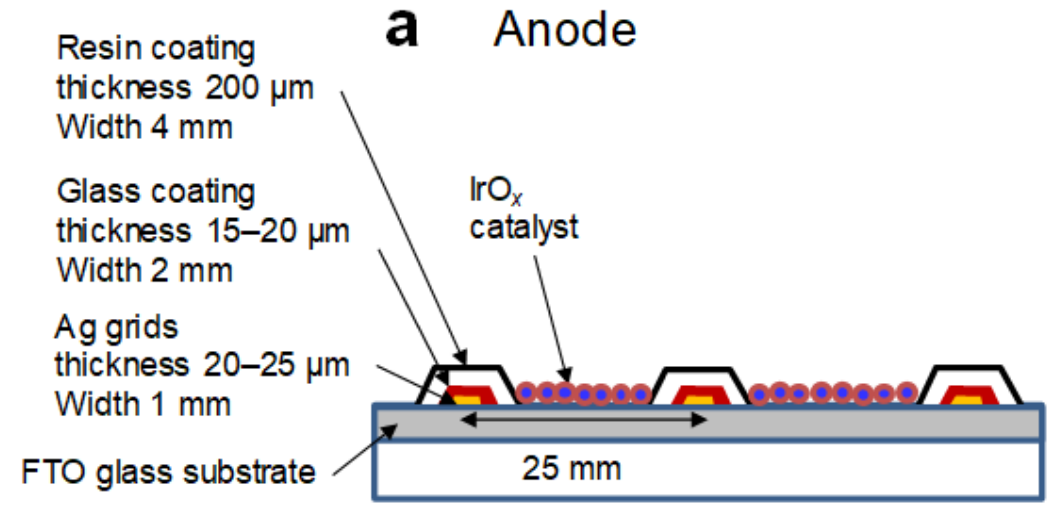

\section{b Cathode}
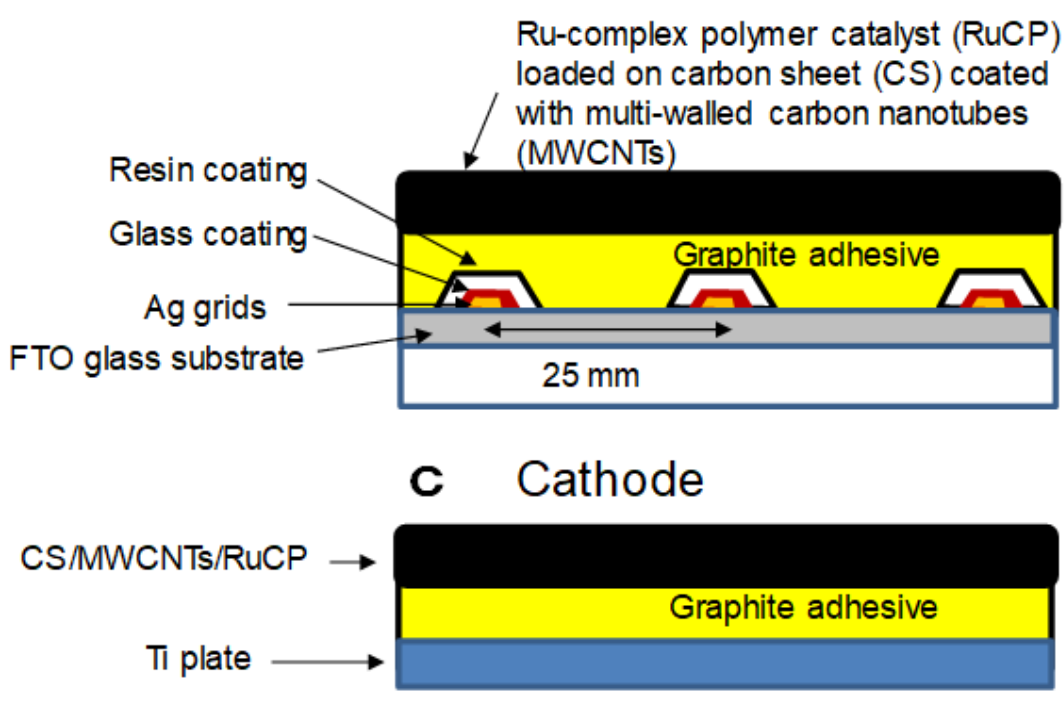

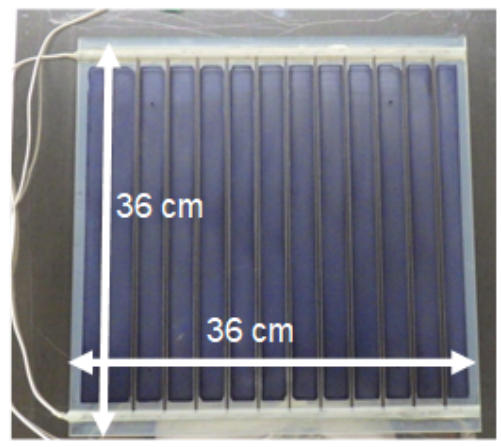

Active area with catalyst: $32 \mathrm{~cm}$ square $=1024 \mathrm{~cm}^{2}$ Substrate size: $36 \mathrm{~cm}$ square

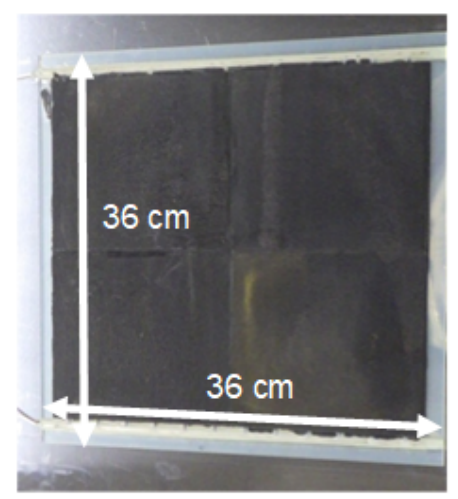

Active area with catalyst: $32 \mathrm{~cm}$ square $=1024 \mathrm{~cm}^{2}$ Substrate size: $36 \mathrm{~cm}$ square

Figure 3

Large-sized cell design. a anode, b cathode with a multilayered Ag grid pattern on glass substrates covered with an F-doped SnO2 layer, and c cathode with Ti plate substrate (not to scale). 


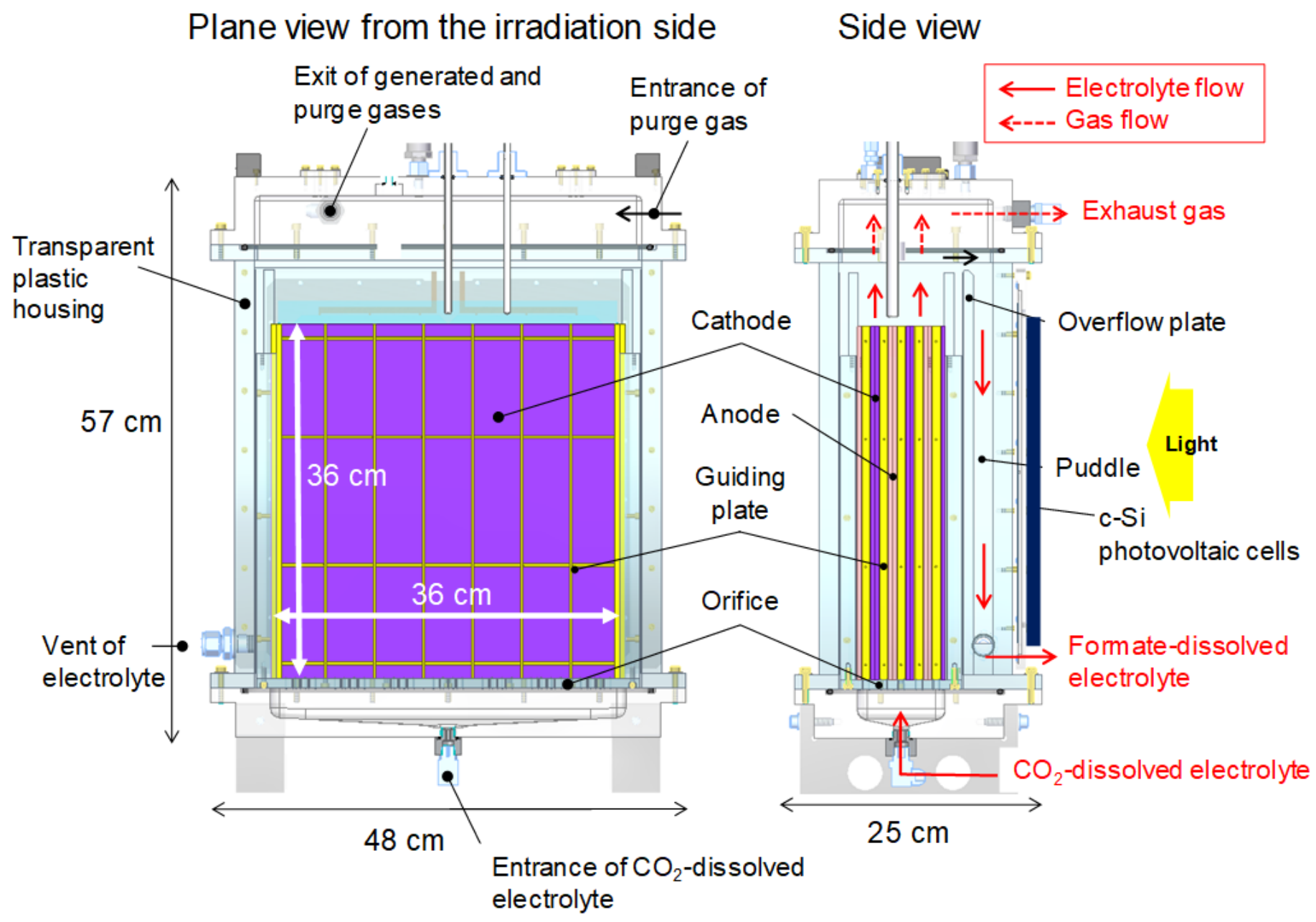

Figure 4

Detailed structure of the large-sized Type B cell equipped with five stacked electrode catalysts. 

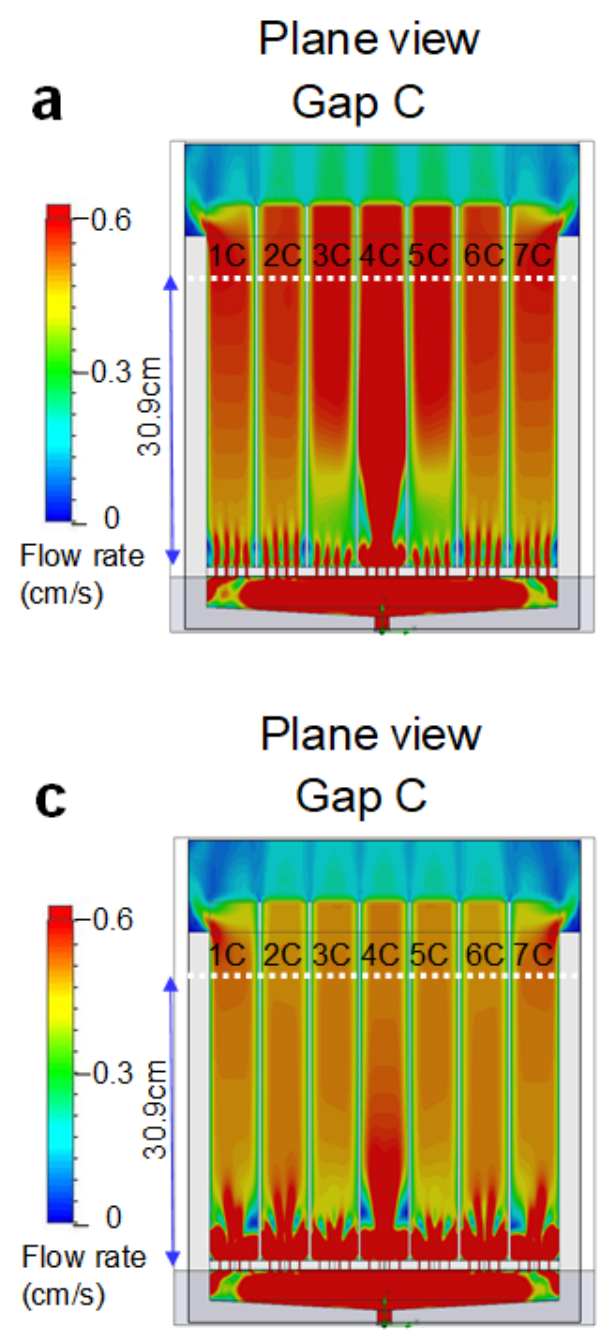
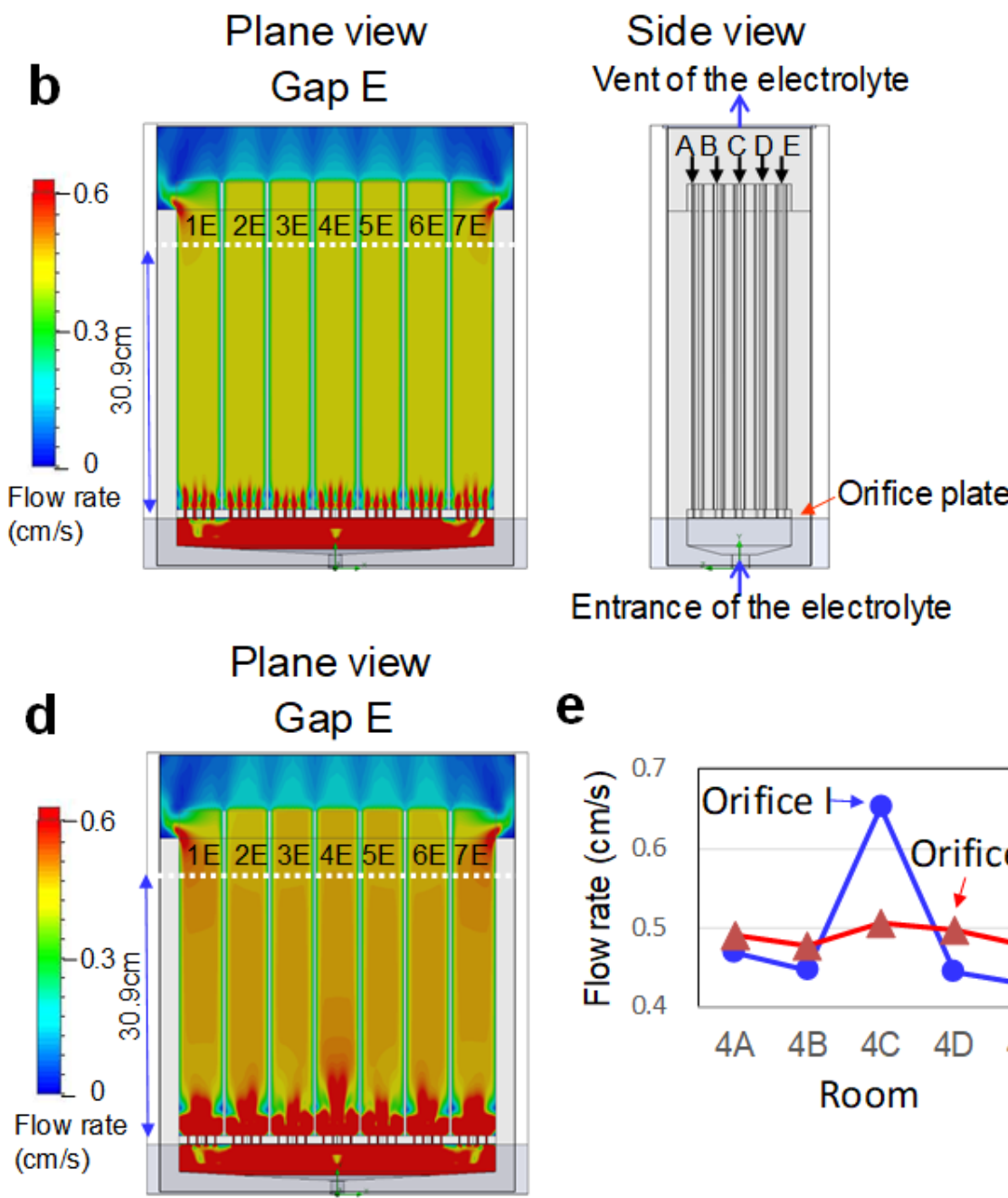

e

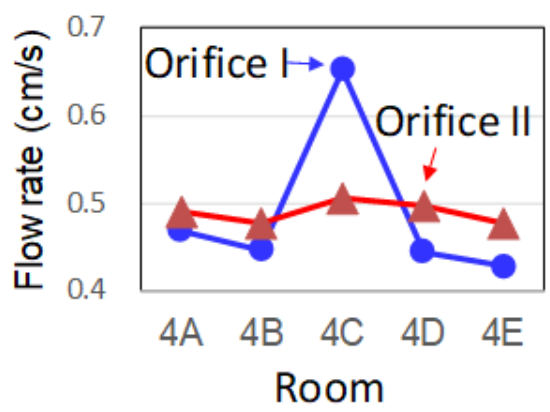

\section{Figure 5}

Flow rate distributions in the large-sized Type B cells. a Gap C using Orifice I, b gap E using Orifice I, c gap C using Orifice ll, and d gap E using Orifice II. e Plots of the flow rates at a distance of $30.9 \mathrm{~cm}$ from the orifice plates. 


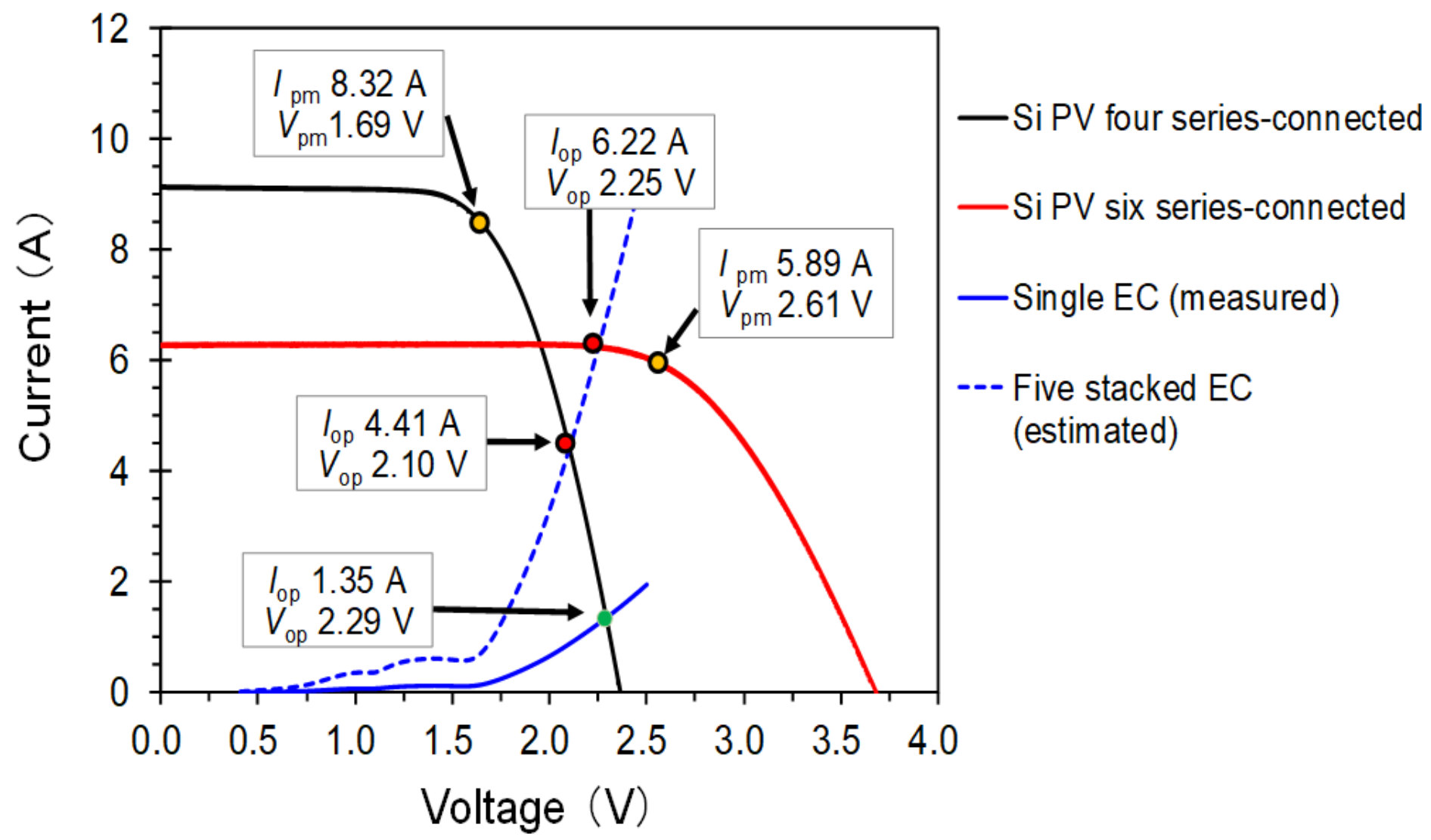

Figure 6

LSV curves of the EC reactors equipped with a single anode-cathode pair and five stacked electrode catalysts as well as current (I)-voltage (V) characteristics of four and six series-connected c-Si PV cells under AM1.5G 1 sun irradiation using the solar simulator. 

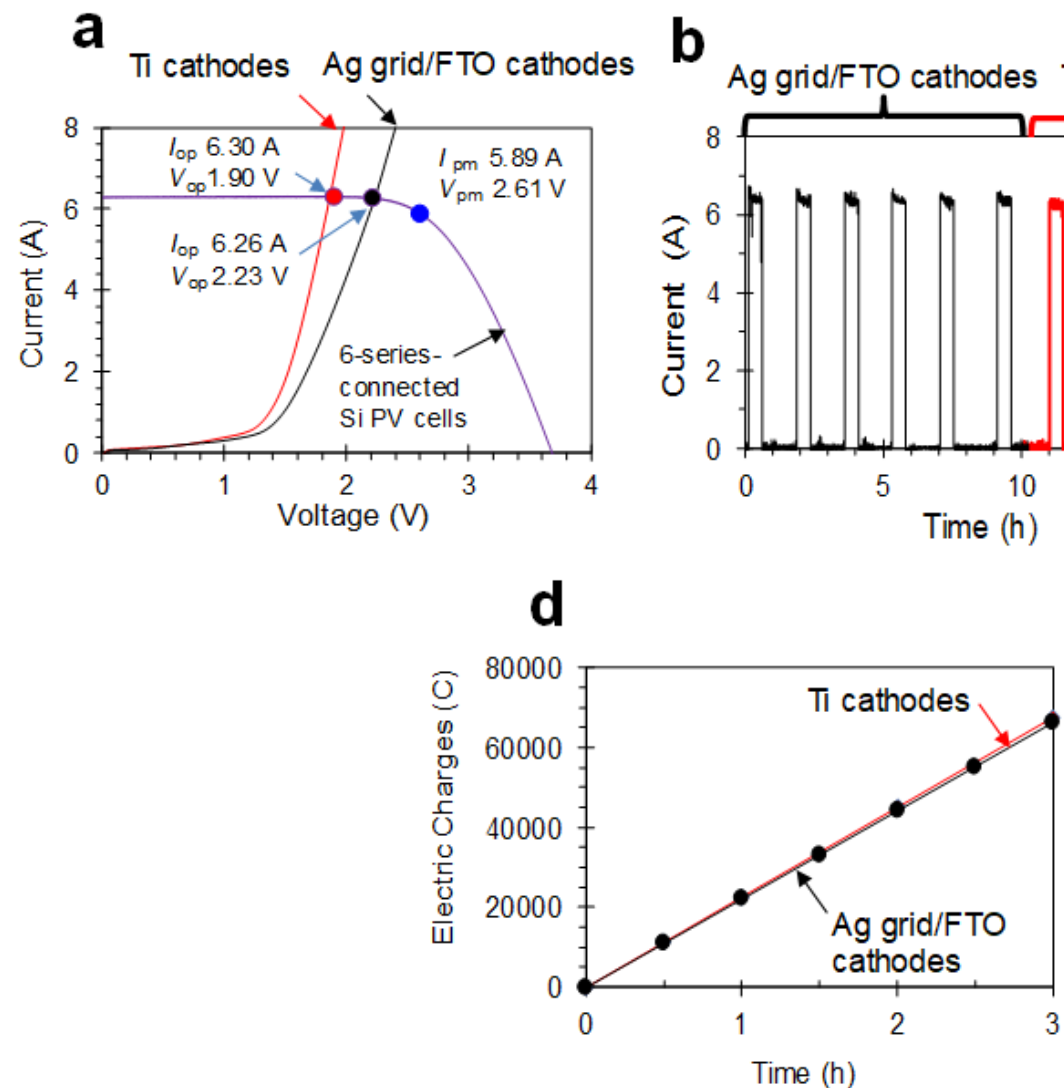

C
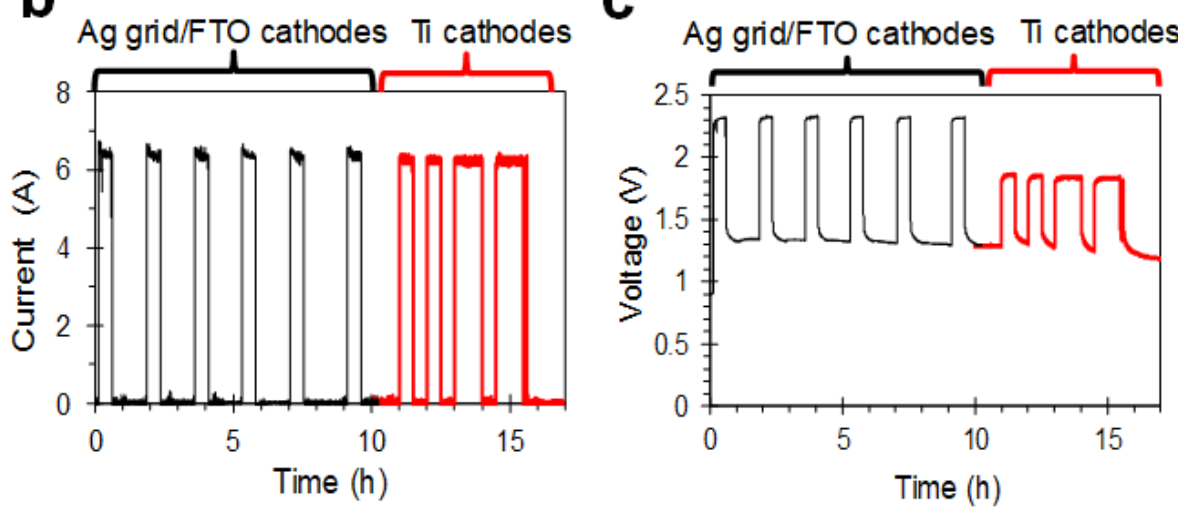

e

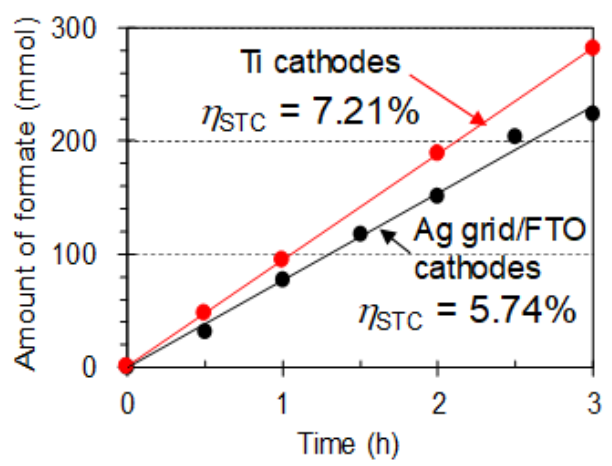

Figure 7

Characteristics of the large cells. a LSV curves of the large cells (Type B) equipped with the stacked Ag grid/FTO cathodes and Ti cathodes and current (I)-voltage (V) characteristics of the six series-connected c-Si-PV cells under AM1.5G 1 sun solar irradiation. b I- $t$ curves and $c$ V- $t$ curves of the cells. Accumulated d electric charge and e amount of formate as functions of the irradiation time. Data of the first measurement are plotted in b-e.

\section{Supplementary Files}

This is a list of supplementary files associated with this preprint. Click to download.

- NatureCommsupplementaryinformation.docx 